\title{
Analisis Perhitungan Tax Shield Approach Dalam Mendeterminasikan Arus Kas Operasional
}

\author{
Analysis of Tax Shield Approach Calculations in Determining Operating Cash Flow
}

\author{
Nurul Izzah Lubis ${ }^{1}$, Ade Mawarni' ${ }^{2}$ \\ Program Studi Akuntansi, Fakultas Ekonomi dan Bisnis, \\ Universitas Potensi Utama \\ e-mail: nurulizzah.potensi@gmail.com
}

\begin{abstract}
ABSTRAK
Tax Shield Approach merupakan salah satu pendekatan untuk menghitung dan menganalisis Arus Kas Operasional suatu perusahaan. Penelitian ini bertujuan untuk menghitung dan menganalisis Tax Shield Approach dalam mendeterminasikan Arus Kas Operasional pada 9 perusahaan sub sector Konstruksi dan Bangunan periode 2017-2019 dengan jenis penelitian deskriptif sebagai analisis keberlanjutan. Tax Shield approach menggunakan indikator EBIT, Tarif Pajak, dan Depresiasi sebagai penyatu rumus. Adapun pendekatan ini dapat digunakan untuk dua manfaat yaitu manajemen perusahaan dan manajemen pajak. Kesimpulan yang didapatkan dari penelitian ini adalah pada tahun 2018, EBIT memiliki pertumbuhan sebesar -13\% dari tahun 2017 dan menurun secara signifikan menjadi -73\% di tahun 2019, pertumbuhan depresiasi di tahun 2018 sebesar 29\% dari tahun sebelumnya dan menjadi $21 \%$ di tahun 2019, AKO/OCF memiliki pertumbuhan sebesar -7\% di tahun 2018 dan menurun menjadi $-55 \%$ di tahun $2019 . \quad$ Dari segi manajemen perusahaan, AKO/OCF yang menurun menjadi masalah bagi nilai perusahaan dan harus ditingkatkan untuk menjaga kepercayaan public maupun investor/kreditur. Dari segi manajemen perpajakan, AKO/OCF yang menurun menandakan Tax Shield atau perencanaan pajak yang baik karena dapat menghindari pajak untuk mengecilkan pengeluaran beban pajak penghasilan tanpa melanggar UU perpajakan.
\end{abstract}

Kata Kunci : Tax Shield approach; Arus Kas Operasional; EBIT; Tarif Pajak; Depresiasi

\section{ABSTRACT}

The Tax Shield Approach is an approach to calculate and analyze a company's Operating Cash Flow. This study aims to calculate and analyze the Tax Shield Approach in determining Operational Cash Flows in 9 Construction and Building sub-sector companies for the period 2017-2019 with the research method as description and analysis. The Tax Shield approach uses EBIT, Tax Rate, and Depreciation indicators as a unifying formula. This approach can be used for two benefits, namely company management and tax management. The conclusion obtained from this study is that in 2018, EBIT had a growth of -13\% from 2017 and decreased significantly to $-73 \%$ in 2019, the growth of depression in 2018 was $29 \%$ from the previous year and became 21\% in 2017. In 2019, AKO/OCF grew by -7\% in 2018 and decreased to -55\% in 2019. From a company management perspective, declining AKO/OCF is a problem for company value and must be increased to maintain public trust and investors/creditors. In terms of tax management, AKO/OCF signifies a good Tax Shield or tax planning because it can avoid taxes to reduce income taxes without violating tax laws.

Keywords : Tax Shield approach; Operating Cash Flow; EBIT; Tax Rate; Depreciation

\author{
Disubmit: 12 November $2021 \quad$ Direview: 17 Desember $2021 \quad$ Diterima :15 Januari 2022
}

Copyright (C) 2022 - Journal Accumulated. All rights reserved.

\section{PENDAhULUAN}

Pertumbuhan perusahaan merupakan hal penting yang harus dijaga untuk keberlangsungannya, terutama perusahaan yang sudah go-public, agar dapat terus menjamin kepercayaan masyarakat maupun investor khusunya. Banyak faktor yang dapat ditentukan untuk melestarikan pertumbuhan perusahaan yang baik, antaranya tentunya pendapatan yang meningkat, pertumbuhan penjualan 
yang pesat, penurunan biaya yang besar, penggunaan modal yang baik dan arus kas yang berkelanjutan mumpuni menjadi jaminan perusahaan dalam meneruskan kegiatannya.

Salah satu faktor yang dapat digunakan untuk menganalisis pertumbuhan perusahaan adalah arus kas. Menurut Miqdad Zuhry Azra (2018:194), arus kas dapat diartikan sebagai suatu laporan yang mengemukakan penerimaan, pengeluaran kas dan saldo kas bersih suatu perusahaan dengan menyangkut tiga aktivitas inti yaitu operasi, investasi dan pendanaan pada periode yang ditentukan. Dengan adanya arus kas dalam tiga aktivitas perusahaan tersebut, investor mendapatkan akses laporan yang berfungsi untuk menilai kemampuan perusahaan dalam pengelolaan kas dan membantu dalam pengambilan sebuah keputusan untuk future short/long plans khususnya kegiatan investasi dan pendanaan.

Arus kas operasi adalah faktor penting dalam kegiatan usaha sebuah perusahaan yang dapat digunakan untuk berbagai fungsi, seperti pengambilan keputusan dalam penganggaran modal baik ditinjau dari penghematan biaya maupun peningkatan beban. Adapun sesuai PSAK No. 2 (2015) bahwa arus kasi dari aktivitas operasi adalah, aktivitas penghasilan utama dari pendapatan entitas dan aktivitas lainnya yang bukan merupakan aktivitas investasi dan pendanaan.

Arus kas operasi menyangkut transfer uang aktual ke dan dari perusahaan. Investor akan melihat arus kas operasi perusahaan untuk menentukan apakah perusahaan menghasilkan cukup uang untuk menutupi biayanya dengan sisa yang cukup untuk hal-hal seperti pertumbuhan, penelitian dan pengembangan, membayar dividen, dan membayar kembali utang. Pada saat yang sama, perusahaan juga akan melihat arus kas operasi untuk melihat apakah mereka memiliki uang untuk mengembangkan bisnis mereka baik dengan uang tunai atau melalui pinjaman. Sebagai contoh, perusahaan perlu tahu jika mereka membeli peralatan dengan harga tertentu, mereka akan memiliki cukup uang untuk membayarnya kembali seiring waktu.

Hal yang harus selalu diperhatikan adalah arus kas tidak sama dengan laba bersih suatu perusahaan. Laporan laba rugi, yang menghitung laba bersih, menunjukkan nilai bisnis pada titik waktu tertentu. Namun, ketika bisnis melaporkan pendapatan bersih mereka, mereka memasukkan transaksi apa pun yang tidak memiliki transfer uang tunai yang sebenarnya, seperti depresiasi. Karena hal tersebut maka arus kas operasi dapat secara khusus mengacu pada transfer tunai.

Ada tiga pendekatan berbeda yang digunakan perusahaan untuk menghitung arus kas operasi mereka: bottom-up, top-down, dan Tax Shield. Pendekatan bottom-up dan top-down keduanya dimulai dengan item pada laporan laba rugi. Pendekatan bottom-up dimulai di bagian bawah laporan laba rugi, dengan laba bersih, dan menambahkan kembali ke laba bersih sejumlah depresiasi. Penyusutan adalah pengurangan nilai peralatan atau mesin untuk setiap tahun penggunaannya. Hal ini bukan merupakan transaksi tunai, namun hanya cara untuk menyebarkan nilai peralatan tersebut dari waktu ke waktu, yang menunjukkan bahwa mesin yang telah dibeli enam tahun lalu tidak bernilai sama pada hari ini. Sehingga rumus bottom-up untuk menghitung arus kas operasi perusahaan adalah seperti berikut: Laba bersih + depresiasi.

Pendekatan top-down juga dimulai dengan angka-angka dari laporan laba rugi. Namun, itu dimulai dengan item-item dari atas. Rumus top-down untuk menghitung arus kas operasi perusahaan datang dalam tiga bagian. Perhitungan pertama yaitu: Penjualan - pengeluaran depresiasi = EBIT $($ Earning Before Interest and Tax). Kemudian hasil tersebut digunakan untuk perhitungan kedua yaitu: EBIT $\mathrm{x}$ tarif pajak = pajak yang dibayarkan. Sehingga, keduanya digabungkan untuk mendapatkan OCF: EBIT - pajak dibayar + depresiasi.

Adapun pendekatan Tax Shield merupakan formulasi yang sangat berguna ketika arus kas tambahan utama adalah pembelian peralatan dan depreciation Tax Shield yang terkait, seperti ketika memilih antara dua mesin. Dengan adanya pendekatan arus kas operasi menggunakan Tax Shield ini maka penelitian ini diterapkan pada sub sektor Konstruksi dan Bangunan untuk periode 2017-2019.

Penelitian ini bertujuan untuk menghitung dan menganalisis Tax Shield approach dalam mendeterminasikan Arus Kas Operasi pada Sub Sektor Konstruksi dan Bangunan. Dengan adanya 
tujuan dan dari latar belakang tersebut, maka terbentuk pertanyaan penelitian yaitu: Bagaimana Perhitungan dan Analisis Tax Shield Approach Dalam Mendeterminasikan Arus Kas Operasi Pada Sub Sektor Konstruksi dan Bangunan Periode 2017-2019?

\section{TINJAUAN LITERATUR}

\section{A. Arus Kas Operasi}

Jumlah arus kas berdasarkan kegiatan operasi adalah indikator yg memilih apakah berdasarkan operasinya perusahaan dapat membentuk arus kas yang relatif untuk melunasi pinjaman, memelihara kemampuan operasi perusahaan, membayar deviden dan melakukan investasi baru tanpa mengandalkan dalam asal pendanaan perusahaan (PSAK 2004 No. 2, paragraf 12). Arus kas berdasarkan kegiatan operasien meruapakan penghasil primer pendapatan perusahaan. Oleh lantaran itu, arus kas tadi dalam umumnya berdasarkan transaksi dan insiden lain yang mensugesti pendapatan laba atau rugi bersih. Beberapa model arus kas berdasarkan operasi adalah : (PSAK 2004 No. 2, paragraf 13)

a) Penerimaan kas dari penjualan barang atau jasa.

b) Penerimaan kas dari royalti, komisi dan pendapatan lain.

c) Pembayaran kas kepada pemasok barang atau jasa.

d) Pembayaran kas kepada karyawan.

e) Penerimaan dan pembayaran kas oleh perusahaan asuransi sehubungan dengan premi, klain, anuitas dan manfaat asuransi lainnya.

f) Pembayaran kas atau penerimaan kembali pajak penghasilan kecuali jika dapat diidentifikasikan secara khusus sebagai bagian dari aktivitas pendanaan dan investasi.

g) Penerimaan dan pembayaran kas dari kontrak yang diadakan untuk tujuan transaksi usaha dan perdagangan.

\section{B. Tax Shield}

Tax Shield adalah pengurangan penghasilan kena pajak untuk individu atau perusahaan yang dicapai dengan mengklaim pengurangan yang diizinkan seperti bunga hipotek, biaya pengobatan, sumbangan amal, amortisasi, dan depresiasi. Pengurangan ini mengurangi penghasilan kena pajak wajib pajak untuk tahun tertentu atau menunda pajak penghasilan ke tahun-tahun mendatang. Tax Shield menurunkan jumlah keseluruhan pajak yang terutang oleh wajib pajak perorangan atau bisnis. (Pablo F., 2010)

Pengurangan depresiasi memungkinkan pembayar pajak untuk memulihkan kerugian tertentu yang terkait dengan depresiasi properti yang memenuhi syarat. Pengurangan dapat berlaku untuk properti berwujud, seperti kendaraan dan bangunan, serta aset tidak berwujud, seperti perangkat lunak komputer dan paten. Agar memenuhi syarat, penyusutan harus dikaitkan dengan aset yang digunakan dalam bisnis atau aktivitas yang menghasilkan pendapatan, dan memiliki umur yang diharapkan lebih dari satu tahun. Kondisi lain dapat mempengaruhi kemampuan penyusutan untuk dikurangkan, termasuk, namun tidak terbatas pada, durasi kepemilikan aset dan apakah aset tersebut digunakan untuk membangun peningkatan modal.

\section{Tax Shield Approach dalam mendeterminasikan Arus Kas Operasi (Operating Cash Flow Tax Shield Approach)}

Arus kas operasi adalah uang tunai yang dihasilkan dari operasi normal perusahaan. Penganggaran modal sangat penting ketika membuat keputusan perusahaan yang penting. Hal ini membantu dalam merencanakan investasi jangka panjang sebuah organisasi. Hal ini berguna untuk 
mengukur margin kas yang dihasilkan oleh operasi perusahaan. Pendekatan OCF Tax Shield adalah teknik yang digunakan dalam memperkirakan penganggaran modal suatu perusahaan. (J.R. Graham, 2016)

Sebagaimana yang diketahui, perhitungan Arus Kas Operasi dapat menggunakan tiga pendekatan yaitu Bottom-Up Approach, Top-Down Approach dan Tax Shield Approach. Gambar dibawah menunjukkan contoh perbedaan pendekatan dalam menghitung Arus Kas Operasi :

\section{Bottom-Up Approach:}

$\mathrm{OCF}=$ Net Income + Depreciation

$\$ 7,200+\$ 6,000=\$ 13,200$

\section{Top-Down A pproach:}

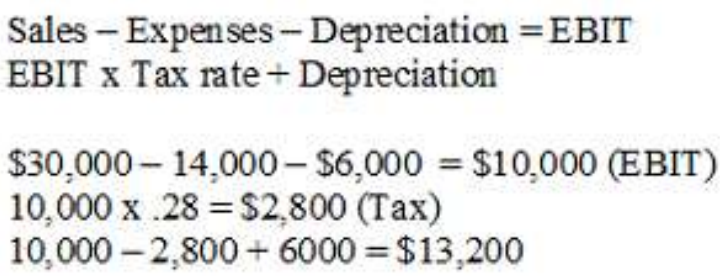

Tax Shield Approach:

(Sales - Expenses) $(1-$ Tax $)+$ Depreciation $\mathrm{x}$ Tax

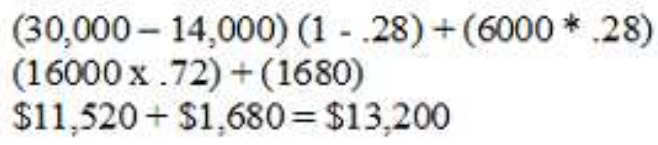

Gambar 1. Contoh Pendekatan Perhitungan Arus Kas Operasi (1)

Dapat dilihat dari gambar 1, pendekatan Bottom-Up Approach menggunakan perhitungan dimana Net Income (Pendapatan Bersih) ditambah Depreciation (Depresiasi). Sementara jika menggunakan Top-Down Approach menggunakan perhitungan yang lebih kompleks lagi dimana Sales (Penjualan) dikurang dengan Expenses (Biaya) dan Depreciation (Depresiasi) yang sama dengan Earning Before Interest and Tax (EBIT).

Namun untuk pendekatan Tax Shield, menggunakan Sales (Penjualan) dikurangi Expenses (Biaya) dikali 1 dikurangi Tax (Pajak) yaitu tariff pajak dan ditambah dengan Depreciation dikalikan dengan Tax. Sehingga dengan pendekatan ini, menggunakan pajak sebagai pendekatan perencanaan pajak.

Contoh lain dari perbedaan pendekatan perhitungan Arus Kas Operasi dapat dilihat dari gambar berikut : 


\section{Operating Cash Flow (6 of 7$)$}

\section{3 more ways to calculate OCF:}

\section{1.)The Bottom-Up Approach}

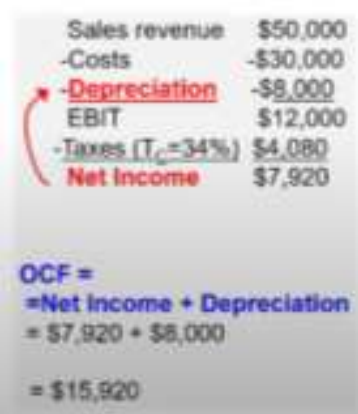

\section{2.) The Top-Down Approach}

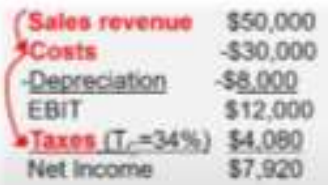

OCF $=$
$=$ Sales - Costs - Taxes $=\$ 50,000-\$ 30,000-\$ 4,080$

$=\$ 15920$

\section{3.) The Tax Shield} Approach

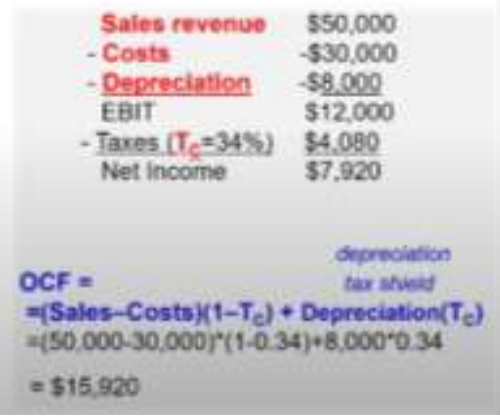

Sumber: Dr. Ekaterina Chernobai (youtube.com)

\section{Kerangka Konseptual}

Kerangka konseptual dari penelitian ini dapat dilihat pada gambar dibawah:

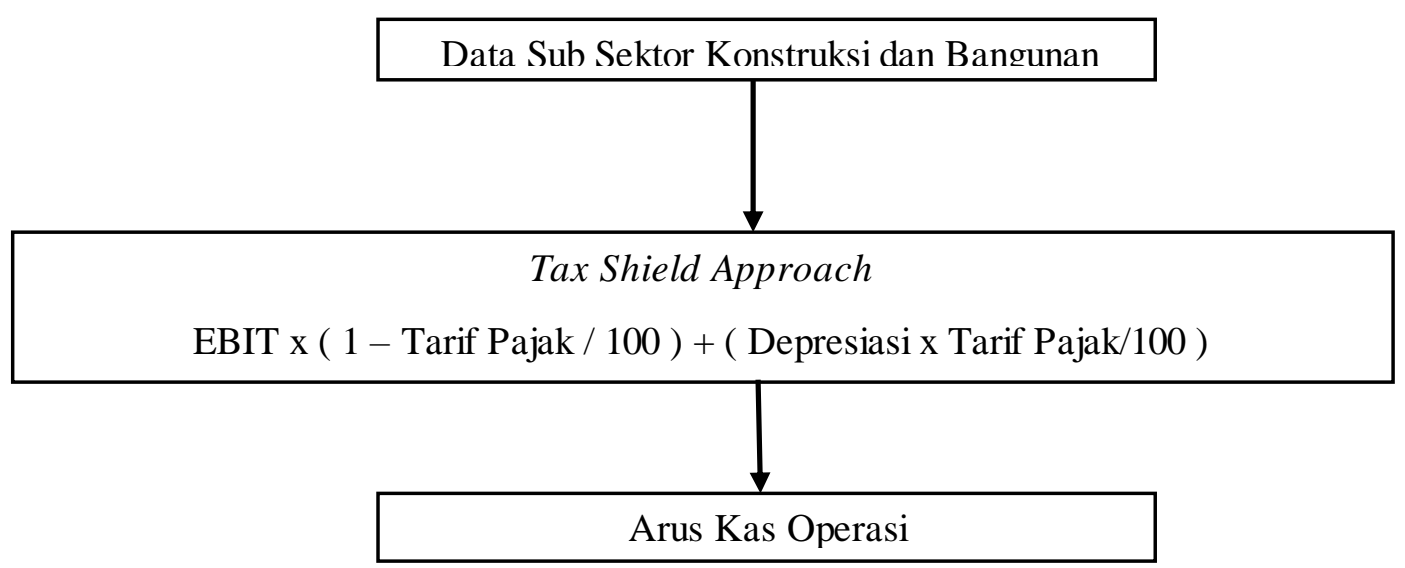

Gambar 3. Kerangka Konseptual

Penelitian ini menggunakan data laporan keuangan dari perusahaan-perusahaan pada sub-sektor Konstruksi dan Bangunan untuk menghitung Arus Kas Operasional menggunakan pendekatan Tax Shield, untuk mengetahui perbandingan Arus Kas Operasional dari laporan keuangan dan Arus Kas Operasional menggunakan tax shield approach.

\section{METODE}

Penelitian ini menggunakan pendekatan penelitian deskriptif dengan metode deskriptif keberlanjutan. Tempat penelitian yang diambil adalah perusahaan yang termasuk dalam sub sektor 
Konstruksi dan Bangunan yang terdaftar di BEI dan telah memenuhi kriteria yang dibutuhkan dalam penelitian ini yaitu data laporan tahunan yang tersedia dan dapat diakses (diunduh) dari tahun 2017 sampai dengan tahun 2019. Sehingga dengan metode purposive sampling, maka terdapat 9 perusahaan yang memenuhi kriteria-kriteria yang dibutuhkan. Perusahaan yang menjadi sampel penelitian dapat dilihat dari tabel dibawah ini:

Tabel 1. Perusahaan Sub Sektor Konstruksi dan Bangunan yang memenuhi kriteria

\begin{tabular}{|c|l|l|c|c|c|c|}
\hline \multirow{2}{*}{ No. } & \multirow{2}{*}{ Kode } & \multicolumn{2}{|c|}{ Nama Perusahaan } & \multirow{2}{*}{ IPO Dates } & \multicolumn{3}{|c|}{ Krite ria } \\
\cline { 5 - 7 } & & & $\mathbf{2 0 1 7}$ & $\mathbf{2 0 1 8}$ & $\mathbf{2 0 1 9}$ \\
\hline 1 & ACST & Acset Indonusa Tbk & $24-06-2013$ & $\sqrt{ }$ & $\sqrt{ }$ & $\sqrt{ }$ \\
\hline 2 & CSIS & $\begin{array}{l}\text { Cahayasakti Investindo Sukses } \\
\text { Tbk }\end{array}$ & $10-05-2017$ & $\sqrt{ }$ & $\sqrt{ }$ & $\sqrt{ }$ \\
\hline 3 & DGIK & Nusa Konstruksi Enjiniring Tbk & $19-12-2007$ & $\sqrt{ }$ & $\sqrt{ }$ & $\sqrt{ }$ \\
\hline 4 & IDPR & Indonesia Pondasi Raya Tbk & $10-12-2015$ & $\sqrt{ }$ & $\sqrt{ }$ & $\sqrt{ }$ \\
\hline 5 & NRCA & Nusa Raya Cipta Tbk & $27-06-2013$ & $\sqrt{ }$ & $\sqrt{ }$ & $\sqrt{ }$ \\
\hline 6 & SSIA & Surya Semesta Internusa Tbk & $27-03-1997$ & $\sqrt{ }$ & $\sqrt{ }$ & $\sqrt{ }$ \\
\hline 7 & TOTL & Total Bangun Persada Tbk & $25-07-2006$ & $\sqrt{ }$ & $\sqrt{ }$ & $\sqrt{ }$ \\
\hline 8 & WIKA & Wijaya Karya Persero Tbk & $29-10-2007$ & $\sqrt{ }$ & $\sqrt{ }$ & $\sqrt{ }$ \\
\hline 9 & WSKT & Waskita Karya Persero Tbk & $19-12-2012$ & $\sqrt{ }$ & $\sqrt{ }$ & $\sqrt{ }$ \\
\hline
\end{tabular}

Sumber data: Data diolah (BEI)

Jenis data yang digunakan dalam penelitian ini merupakan data sekunder yang diakses melalui $w w w . i d x . c o . i d$ yaitu laporan keuangan dan tahunan 9 perusahaan di sub sektor Konstruksi dan Bangunan yang terdaftar di BEI yang memenuhi kriteria dari tahun 2017-2019 dengan penunjang data seperti hasil penelitian terdahulu, teori utama dan pendukung yang relevan, buku-buku literatur, jurnal atau artikel ilmiah dan situs resmi lainnya.

Teknik analisis data yang digunakan adalah analisis Tax Shield Approach dalam mendeterminasikan Arus Kas Operasi (OCF Tax Shield Approach). OCF Tax Shield Approach adalah pendekatan yang dapat digunakan untuk menghitung dan menganalisis Arus Kas Operasi selain dari penggunaan pendekatan top-down atau bottom-up. Berikut adalah tabel yang menunjukkan definisi operasional dari beberapa variabel yang terkait dengan perhitungan OCF Tax Shield Approach:

Table 2. Definisi Operasional

\begin{tabular}{|c|c|c|c|}
\hline No. & Variabel & Definisi & Indikator \\
\hline 1. & EBIT & $\begin{array}{l}\text { EBIT adalah Earnings before } \\
\text { Interest and Tax yang memiliki arti } \\
\text { pendapatan sebelum adanya bunga } \\
\text { dan pajak. Pendapatan ini adalah } \\
\text { suatu tolak ukur profitabilitas di } \\
\text { dalam suatu perusahaan } \\
\text { (Investopedia, 2018). }\end{array}$ & $\begin{array}{c}\mathrm{EBIT}= \\
\frac{\text { Pendapatan } / \text { Penjualan }}{\text { Beban/Biaya }}\end{array}$ \\
\hline 2. & Tarif Pajak & $\begin{array}{l}\text { Berdasarkan Pasal } 17 \text { ayat (1) } \\
\text { bagian b UU No. } 36 \text { Tahun } 2008 \\
\text { tentang Pajak Penghasilan, tarif } \\
\text { pajak yang dikenakan kepada badan } \\
\text { adalah 25\%. Besar tarif ini berlaku } \\
\text { sejak tahun pajak 2010. Tarif lebih } \\
\text { rendah dapat dikenakan kepada } \\
\text { wajib pajak badan dalam negeri } \\
\text { dengan ketentuan tertentu } \\
\text { (djp.go.id, 2021) }\end{array}$ & $\begin{array}{c}\text { Tarif Pajak }= \\
\frac{\text { Beban Pajak }}{\text { LabaFiskal }}\end{array}$ \\
\hline
\end{tabular}




\begin{tabular}{|c|c|c|c|}
\hline 3. & Depresiasi & $\begin{array}{l}\text { Depresiasi atau penyusutan adalah } \\
\text { alokasi jumlah yang bisa disusutkan } \\
\text { dari sebuah aset sepanjang masa } \\
\text { manfaat yang estimasi. Jumlah } \\
\text { yang bisa di susutkan dari aset } \\
\text { adalah biaya yang dikeluarkan } \\
\text { untuk mendapatkan aset tersebut di } \\
\text { kurangi estimasi sisa (salvage } \\
\text { value) aset itu di akhir masa } \\
\text { manfaatnya. (Surya, 2012:173) }\end{array}$ & $\begin{array}{c}\text { Depresiasi }= \\
\text { (Laporan Keuangan) }\end{array}$ \\
\hline 4. & $\begin{array}{l}\text { Arus Kas Operasi } \\
\text { (OCF) }\end{array}$ & $\begin{array}{l}\text { Jumlah arus kas berdasarkan } \\
\text { kegiatan operasi adalah indikator } \\
\text { yang memilih apakah berdasarkan } \\
\text { operasinya perusahaan dapat } \\
\text { membentuk arus kas yang relatif } \\
\text { untuk melunasi pinjaman, } \\
\text { memelihara kemampuan operasi } \\
\text { perusahaan, membayar deviden dan } \\
\text { melakukan investasi baru tanpa } \\
\text { mengandalkan dalam asal } \\
\text { pendanaan perusahaan (PSAK } \\
\text { 2015, No. 2) }\end{array}$ & $\begin{array}{c}\text { OCF }= \\
\text { EBIT } \times\left(1-\frac{T P}{100}\right)+ \\
\left(D \times \frac{T P}{100}\right) \\
\text { *Keterangan: } \\
\text { TP = Tarif Pajak } \\
\mathrm{D}=\text { Depresiasi }\end{array}$ \\
\hline
\end{tabular}

Sumber data: Data diolah

\section{HASIL DAN PEMBAHASAN}

Dalam penelitian ini, data yang digunakan adalah data dari 9 perusahaan sub sektor Konstruksi dan Bangunan yang terdaftar di Bursa Efek Indonesia dari tahun 2017 sampai dengan tahun 2019 dengan kriteria publikasi laporan keuangan/tahunan yang lengkap dan dapat diakses.

Penggunaan analisis OCF Tax Shield Approach yang dapat digunakan oleh jenis perusahaan yang memiliki aset tetap dan pengeluaran investasi yang besar sehingga berpeluang untuk memilih pendekatan ini dalam perhitungan capital budgeting guna mengambil keputusan jangka pendek maupun panjang perusahaan. Pada saat yang sama, pendekatan ini juga membantu perusahaan dalam perencanaan pajak yang tidak melanggar aturan-aturan maupun undang-undang pemerintah.

Menganalisis atau menghitung dengan Tax Shield Approach harus memperhatikan rumus dan indikator yang digunakan. Kesalahan seringkali terjadi pada pengambilan angka untuk Earning Before Interest and Tax (EBIT) karena kekeliruan pada nominal EBIT maupun EBITDA. Be gitu juga pada penggunaan tarif pajak, yang mana tarif pajak dapat didasari dari PPh Badan sesuai UU, adapun perhitungan PPh Badan Efektif sudah menjadi perhitungan Tax Shield sendiri sehingga kurang bersesuaian dengan pendekatan OCF Tax Shield Approach ini. Perlu diingat bahwa tujuan dari penelitian ini adalah untuk mengetahui Arus Kas Operasi menggunakan pendekatan Tax Shield yang notabene baru akan diperhitungkan dalam pendekatan ini dan bukannya telah dihitung sebelumnya.

Berikut adalah hasil dan pembahasan analisis OCF Tax Shield Approach yang penulis peroleh dari data yang diolah pada 9 perusahaan sub sector Konstruksi dan Bangunn yang terdaftar di BEI selama periode tiga tahun terhitung dari tahun 2017 sampai dengan tahun 2019. Sebelumnya, penulis akan menjelaskan analisis dan perhitungan pendekatan ini satu per satu yang selanjutnya digunakan sebagai pelengkap analisis Arus Kas Operasi (OCF) bagi sub sector ini. 
Table 3. Perhitungan OCF Tax Shield Approach Pada 9 Perusahaan Sub Sector

Konstruksi Dan Bangunan Periode 2017-2019

\begin{tabular}{|c|c|c|c|c|c|c|c|}
\hline No & Kode & Tahun & $\begin{array}{l}\text { EBIT } \\
\text { (Rp.) }\end{array}$ & $\begin{array}{c}(1- \\
\text { TP/100) }\end{array}$ & $\begin{array}{l}\text { Depresiasi } \\
\text { (Rp.) }\end{array}$ & TP/100 & $\begin{array}{c}\mathrm{AKO} / \mathrm{OCF} \\
(\text { Rp. })\end{array}$ \\
\hline \multirow[t]{3}{*}{1} & ACST & 2017 & 156,775 & 0,75 & 301,286 & 0,25 & 192,903 \\
\hline & & 2018 & 24,226 & 0,75 & 371,570 & 0,25 & 111,062 \\
\hline & & 2019 & $(1,127,530)$ & 0,75 & 505,572 & 0,25 & $(719,255)$ \\
\hline \multirow[t]{3}{*}{2} & CSIS & 2017 & $1,008,900,166$ & 0,75 & $1,113,090,327$ & 0,25 & $1,034,947,706$ \\
\hline & & 2018 & $(34,349,341,905)$ & 0,75 & $3,681,916,716$ & 0,25 & $(24,841,527,250)$ \\
\hline & & 2019 & $\begin{array}{l}(9,501,092,892) \\
\end{array}$ & 0,75 & $4,195,492,733$ & 0,25 & $(6,076,946,486)$ \\
\hline \multirow[t]{3}{*}{3} & DGIK & 2017 & $26,247,513,873$ & 0,75 & $1,614,842,536$ & 0,25 & $20,089,346,039$ \\
\hline & & 2018 & $(62,983,698,868)$ & 0,75 & $2,524,737,559$ & 0,25 & $(46,606,589,761)$ \\
\hline & & 2019 & $(21,318,644,536)$ & 0,75 & $2,437,378,439$ & 0,25 & $(15,379,638,792)$ \\
\hline \multirow[t]{3}{*}{4} & IDPR & 2017 & $117,428,862,177$ & 0,75 & $655,019,892,466$ & 0,25 & $251,826,619,749$ \\
\hline & & 2018 & $34,507,778,044$ & 0,75 & $786,002,529,066$ & 0,25 & $222,381,465,800$ \\
\hline & & 2019 & $(273,868,345)$ & 0,75 & $928,631,845,533$ & 0,25 & $231,952,560,125$ \\
\hline \multirow[t]{3}{*}{5} & NRCA & 2017 & $117,932,748,305$ & 0,75 & $250,859,093,755$ & 0,25 & $151,164,334,668$ \\
\hline & & 2018 & $119,834,384,548$ & 0,75 & $276,188,047,761$ & 0,25 & $158,922,800,351$ \\
\hline & & 2019 & $101,155,011,546$ & 0,75 & $293,688,976,717$ & 0,25 & $149,288,502,839$ \\
\hline \multirow[t]{3}{*}{6} & SSIA & 2017 & $1,698,096,567,386$ & 0,75 & $1,155,566,073,458$ & 0,25 & $1,562,463,943,904$ \\
\hline & & 2018 & $125,167,889,151$ & 0,75 & $1,283,827,812,002$ & 0,25 & $414,832,869,864$ \\
\hline & & 2019 & $164,833,004,075$ & 0,75 & $1,398,527,348,359$ & 0,25 & $473,256,590,146$ \\
\hline \multirow[t]{3}{*}{7} & TOTL & 2017 & $234,016,063$ & 0,75 & $185,225,815$ & 0,25 & $221,818,501$ \\
\hline & & 2018 & $206,897,229$ & 0,75 & $190,606,274$ & 0,25 & $202,824,490$ \\
\hline & & 2019 & $112,230,137$ & 0,75 & $212,944,830$ & 0,25 & $137,408,810$ \\
\hline \multirow[t]{3}{*}{8} & WIKA & 2017 & $1,462,391,358$ & 0,75 & $1,757,365,601$ & 0,25 & $1,536,134,919$ \\
\hline & & 2018 & $23,589,628,934$ & 0,75 & $1,565,392,752$ & 0,25 & $18,083,569,889$ \\
\hline & & 2019 & $2,789,255,688$ & 0,75 & $2,059,138,351$ & 0,25 & $2,606,726,354$ \\
\hline \multirow[t]{4}{*}{9} & WSKT & 2017 & $4,620,646,154,705$ & 0,75 & $1,111,812,060,559$ & 0,25 & $3,743,437,631,169$ \\
\hline & & 2018 & $5,536,442,504,008$ & 0,75 & $1,742,806,772,119$ & 0,25 & $4,588,033,571,036$ \\
\hline & & 2019 & $1,328,649,961,839$ & 0,75 & $2,343,986,841,840$ & 0,25 & $1,582,484,181,839$ \\
\hline & & Total & 13,891,918,106,157 & - & $12,248,456,603,996$ & - & 13,481,052,730,617 \\
\hline
\end{tabular}

Sumber data: Data diolah

Dari tabel 3 diatas tertera perhitungan untuk OCF Tax Shield Approach sebagaimana indikatornya telah dijelaskan dalam definisi operasional sebelumnya. EBIT atau Earning Before Interest and Tax menjadi sumber utama dalam perhitungan pendekatan ini selain dari depresiasi atau penyusutan. Hal ini dikarenakan penghasilan sebelum dikurangkan dengan beban pajak merupakan hal utama dalam mengetahui keberlangsungan sebuah perusahaan dan faktor utama mendapatkan nilai arus kas operasional. Sedangkan untuk depresiasi atau penyusutan digunakan untuk mengetahui perkaliannya terhadap Tarif Pajak Badan agar dapat mengetahui angka sebenar dari Tax Shield yang didapatkan dari sebuah perusahaan.

Adapun perhitungan untuk pengurangan tarif pajak (1-TP/100) adalah sebesar 0,75 didapat dari anggapan bahwasanya seluruh perusahaan menggunakan PPh Badan Pajak sesuai UU yaitu 25\%. Perhitungan ini tidak didasari dari Effective Tax Rate namun lebih ke tarif pajak badan sesuai dengan peraturan pemerintah yang telah ditetapkan untuk menghindari adanya perhitungan Tax Shield sebanyak dua kali.

Tabel dibawah ini menunjukkan rata-rata dan pertumbuhan dari OCF Tax Shield Approach selama tiga tahun : 
Tabel 4. Rata-Rata dan Pertumbuhan OCF Tax Shield Approach Pada 9 Perusahaan Sub Sektor Konstruksi dan Bangunan Periode 2017-2019

\begin{tabular}{|c|c|c|c|c|c|c|}
\hline \multirow{2}{*}{ Tahun } & \multicolumn{2}{|c|}{$\begin{array}{c}\text { EBIT } \\
\text { (Rp.) }\end{array}$} & \multicolumn{2}{c|}{$\begin{array}{c}\text { Depresiasi } \\
\text { (Rp.) }\end{array}$} & \multicolumn{2}{c|}{$\begin{array}{c}\text { AKO/OCF } \\
\text { (Rp.) }\end{array}$} \\
\cline { 2 - 7 } & $\overline{\boldsymbol{x}}$ & $\Delta$ & $\overline{\boldsymbol{x}}$ & $\Delta$ & $\overline{\boldsymbol{x}}$ & $\Delta$ \\
\hline 2017 & $6,583,057,310,808$ & - & $3,177,927,945,803$ & - & $5,731,774,969,557$ & - \\
\hline 2018 & $5,742,416,065,367$ & $-13 \%$ & $4,096,788,185,819$ & $29 \%$ & $5,331,009,095,480$ & $-7 \%$ \\
\hline 2019 & $1,566,444,729,982$ & $-73 \%$ & $4,973,740,472,374$ & $21 \%$ & $2,418,268,665,580$ & - \\
& & & \multicolumn{4}{|c|}{}
\end{tabular}

Sumber data: Data diolah

Keterangan :

$\bar{x}:$ Total Rata-Rata

$\bar{\Delta}:$ Pertumbuhan

Dari tabel 4 diatas terlihat rata-rata EBIT untuk tahun 2017 sebesar Rp. 6,583,057,310,808 dan di tahun 2018, penurunan terjadi sehingga EBIT menjadi sebesar Rp. 5,742,416,065,367 dengan pertumbuhan $-13 \%$. Hal yang sama terjadi di tahun 2019, dimana EBIT menurun secara signifikan dari tahun 2018 menjadi sebesar Rp. 1,566,444,729,982 dengan pertumbuhan negatif $73 \%$. Penurunan ini terjadi karena beberapa dari perusahaan sub sector Konstruksi dan Bangunan telah mengalami penurunan bahkan kerugian pada pendapatan sebelum pajak penghasilan dan hal ini menjadi faktor utama terjadinya pertumbuhan yang menurun signifikan.

Depresiasi memiliki rata-rata sebesar Rp. 3,177,927,945,803 di tahun 2017 dan di tahun 2018 menjadi sebesar Rp. 4,096,788,185,819 yang menyebabkan pertumbuhan positif sebesar $29 \%$. Begitu juga di tahun 2019, rata-rata depresiasi meningkat menjadi sebesar Rp. 4,973,740,472,374 dengan pertumbuhan positif $21 \%$. Walau peningkatan telah terjadi dari rata-rata depresiasi namun jika dilihat dari pertumbuhan, depresiasi mengalami penurunan dari tahun 2018 ke 2019 sebanyak $8 \%$.

Pada tahun 2017, rata-rata Arus Kas Operasi adalah sebesar Rp. 5,731,774,969,557 dan pada tahun 2018 menjadi sebesar Rp. 5,331,009,095,480 dan hal ini menunjukkan terjadinya pertumbuhan yang menurun sebanyak negatif 7\%. Untuk tahun 2019, rata-rata Arus Kas Operasi menjadi sebesar Rp. 2,418,268,665,580 dan memiliki pertumbuhan yang menurun secara signifikan dari tahun sebelumnya yaitu sebesar negatif $55 \%$. Penurunan yang terus menerus terjadi dari tahun 2017 sampai dengan tahun 2019 ini dikarenakan EBIT yang menurun dan berpengaruh terhadap besar kecilnya capaian arus kas operasional perusahaan sub sector Konstruksi dan Bangunan yang terdaftar di BEI.

Tabel 5. Perbandingan AKO/OCF dari Laporan Keuangan dan AKO/OCF Tax Shield yang telah dihitung

\begin{tabular}{|r|c|r|r|r|}
\hline No & Kode & Tahun & AKO/OCF (Rp) & AKO/OCF Tax Shield $(\mathbf{R p )}$ \\
\hline 1 & ACST & 2017 & -1.128 .125 & 192.903 \\
\hline & & 2018 & -857.235 & 111.062 \\
\hline & & 2019 & -341.724 & -719.255 \\
\hline 2 & CSIS & 2017 & -112.650 .246 .824 & 1.034 .947 .706 \\
\hline & & 2018 & -21.110 .019 .264 & -24.841 .527 .250 \\
\hline & & 2019 & -67.203 .994 .339 & -6.076 .946 .486 \\
\hline 3 & DGIK & 2017 & -82.734 .972 .334 & 20.089 .346 .039 \\
\hline & & 2018 & -214.353 .247 .056 & -46.606 .589 .761 \\
\hline & & 2019 & -1.629 .787 .345 & -15.379 .638 .792 \\
\hline 4 & IDPR & 2017 & 222.217 .510 .326 & 251.826 .619 .749 \\
\hline & & 2018 & 190.557 .741 .616 & 222.381 .465 .800 \\
\hline & & 2019 & 69.473 .721 .681 & 231.952 .560 .125 \\
\hline
\end{tabular}




\begin{tabular}{|r|c|r|r|r|}
\hline No & Kode & Tahun & AKO/OCF (Rp) & AKO/OCF Tax Shield (Rp) \\
\hline 5 & NRCA & 2017 & 224.101 .889 .245 & 151.164 .334 .668 \\
\hline & & 2018 & -78.264 .587 .937 & 158.922 .800 .351 \\
\hline & & 2019 & -68.373 .075 .003 & 149.288 .502 .839 \\
\hline 6 & SSIA & 2017 & -265.358 .621 .580 & 1.562 .463 .943 .904 \\
\hline & & 2018 & -845.167 .380 .009 & 414.832 .869 .864 \\
\hline & & 2019 & -122.618 .235 .569 & 473.256 .590 .146 \\
\hline 7 & TOTL & 2017 & 226.695 .187 & 221.818 .501 \\
\hline & & 2018 & 158.170 .385 & 202.824 .490 \\
\hline & & 2019 & 154.813 .740 & 137.408 .810 \\
\hline 8 & WIKA & 2017 & 1.885 .252 .166 & 1.536 .134 .919 \\
\hline & & 2018 & 2.722 .531 .219 & 2.083 .569 .889 \\
\hline & & 2019 & 833.091 .329 & 3.743 .437 .631 .169 \\
\hline 9 & WSKT & 2017 & $\mathbf{- 5 . 9 5 9 . 5 6 2 . 4 3 5 . 4 5 9}$ & 4.588 .033 .571 .036 \\
\hline & & 2018 & 3.035 .139 .221 .324 & 1.582 .484 .181 .839 \\
\hline & & 2019 & 9.014 .249 .440 .062 & $\mathbf{5 . 7 3 1 . 7 7 4 . 9 6 9 . 5 5 7}$ \\
\hline & $\bar{x}$ & $\mathbf{2 0 1 7}$ & $\mathbf{- 5 . 9 7 1 . 8 7 6 . 0 5 7 . 3 9 8}$ & $\mathbf{5 . 3 3 1 . 0 0 9 . 0 9 5 . 4 8 0}$ \\
\cline { 2 - 5 } & $\overline{\boldsymbol{x}}$ & $\mathbf{2 0 1 8}$ & $\mathbf{2 . 0 6 9 . 6 8 1 . 5 7 3 . 0 4 3}$ & $\mathbf{2 . 4 1 8 . 2 6 8 . 6 6 5 . 5 8 0}$ \\
\cline { 2 - 5 } & $\overline{\boldsymbol{x}}$ & $\mathbf{2 0 1 9}$ & $\mathbf{8 . 8 2 4 . 8 8 5 . 6 3 2 . 8 3 2}$ & \\
\hline \multirow{2}{*}{$S 4$} & & & \\
\end{tabular}

Sumber data: Data diolah

Keterangan :

$\bar{x}:$ Jumlah

Dengan melihat angka rata-rata Arus Kas Operasi/OCF pada tabel 4 dapat dikatakan secara umum bahwa pada tahun 2017 sampai dengan 2019, 9 perusahaan sub sector Konstruksi dan Bangunan memiliki arus kas operasional yang positif namun terbilang rendah dan menurun dari tahun ke tahun. Hal ini tentunya berpengaruh pada tingkat kepercayaan masyakarat umumnya dan investor khususnya karena akan menjadi alasan dalam pengambilan keputusan, baik dari segi pemberian kredit, pendanaan eksternal, pengkreditan investasi mesin maupun peralatan-peralatan lainnya. Arus kas operasional merupakan salah satu faktor dalam memberikan jaminan bahwa perusahaan tertentu memiliki kekayaan asset yang likuid untuk menjamin dalam pembayaran hutang dan pemberian kredit dari kreditur.

Namun jika dilihat dari tabel 5 dengan membandingkan Arus Kas Operasional dari Laporan Keuangan dan Arus Kas Operasional berbasis Tax Shield yang telah dihitung sebelumnya, terlihat banyak jumlah Arus Kas Operasional yang dilaporkan rendah bahkan dalam keadaan minus. Tetapi jika dilihat dari Arus Kas Operasional berbasis Tax Shield, jumlah yang didapatkan setelah perhitungan menunjukkan nilai positif dan lebih besar dari yang sebenarnya dilaporkan. Seperti contoh pada tabel 5 dengan Kode perusahaan ACST, dimana pada tahun 2017 AKO dari Laporan Keuangan dilaporkan dengan total - Rp.1.128.125, namun dengan menggunakan perhitungan Tax Shield Approach pada arus kas operasional, AKO yang sebenarnya dimiliki ACST di tahun 2017 adalah sebesar Rp. 192.903.

Berbanding terbalik dengan perusahaan ACST, perusahaan dengan kode TOTL yang ada pada sub sector Konstruksi dan Bangunan memiliki jumlah Arus Kas Operasional yang semakin menurun setelah digunakan perhitungan Tax Shield Approach untuk mengetahui besaran Arus Kas Operasional yang sebenarnya. Jika ACST memiliki jumlah AKO yang lebih tinggi dengan perhitungan Tax Shield Approach, sementara TOTL mendapatkan jumlah yang lebih rendah. Terlihat dari tabel 5 tersebut dimana perusahaan TOTL pada tahun 2017 memiliki AKO dari laporan keuangannya sebesar Rp. 226.695.187 namun setelah perhitungan Tax Shield, AKO perusahaan TOTL menjadi sebear Rp. 221.818.501. Harus diingat bahwa Arus Kas Operasional perusahaan pada sub sector Konstruksi dan Bangunan yang dihitung menggunakan Tax Shield Approach memakai factor-faktor yang mendukung hasil perhitungannya yaitu Earning Before Interest and Tax (EBIT), Tarif Pajak dan Depresiasi. EBIT digunakan untuk melihat jumlah laba yang dilaporkan sebelum dikurangi Bunga dan pajak. Sementara tariff pajak yang digunakan 
adalah tarif pajak badan yang ditentukan oleh pemerintah, dalam penelitian ini menggunakan $25 \%$ sebagaimana yang tercantum pada Pasal 17 ayat (1) bagian b UU No. 36 Tahun 2008 tentang Pajak Penghasilan. Hal ini guna menghindari dari pengenaan perencanaan pajak berganda atau yang biasa dikenal sebagai tariff pajak efektif.

Tabel 5 juga menunjukkan perbedaan yang drastis pada jumlah rata-rata Arus Kas Operasional pertahunnya. Dilihat dari tabel pada tahun 2017, rata-rata jumlah AKO dari Laporan Keuangan yaitu sebesar - Rp. 5.971.876.057.398, sementara rata-rata jumlah AKO dari perhitungan pendekatan Tax Shield yaitu sebesar Rp. 5.731.774.969.557. Pada tahun 2018, AKO dari laporan keuangan menunjukkan rata-rata sebesar Rp. 2.069.681.573.043 dan pada jumlah AKO pendekatan Tax Shield terdapat nilai sebesar Rp. 5.331.009.095.480 dimana terlihat perbedaan yang besar pada tahun 2018 tersebut dimana sebenarnya terdapat jumlah Arus Kas Operasional yang tersimpan dan tidak terlaporkan pada Laporan Keuangan perusahaan di sub-sektor Konstruksi dan Bangunan. Hal ini juga menguatkan lagi bahwa beberapa dari perusahaan di sub-sektor tersebut melakukan Tax Shield untuk mengecilkan beban pajak yang harus dibayarkan.

Melihat dari tabel 5 kembali, di tahun 2019 terjadi perbedaan jumlah arus kas operasional yang berbanding terbalik dari tahun 2018. Di tahun 2019, rata-rata Arus Kas Operasional dari laporan keuangan berjumlah Rp. 8.824.885.632.832, namun apabila ditelusuri menggunakan pendekatan Tax Shield, jumlah arus kas operasional menurun drastic menjadi sebesar Rp. 2.418.268.665.580. Penurunan dari perbedaan arus kas operasional menggunakan pendekatan ini tentunya juga dipengaruhi dari EBIT yang dilaporkan pada tahun tersebut sehingga sangat memiliki efek besar pada Tax Shield di arus kas operasional.

Hal lain yang dapat dianalisis dari hasil perhitungan Arus Kas Operasi dengan pendekatan Tax Shield ini adalah dapat dikatakan bahwa angka perencanaan pajak perusahaan juga cenderung menurun dari tahun ke tahun, dan hal ini merupakan suatu yang baik jika dilihat dari sisi manajemen pajak (N. Simkova, 2015). Dengan menurunnya angka perencanaan pajak maka dapat dikatakan manajemen pajak memiliki kesempatan untuk menghindari pembayaran pajak yang tinggi dan masih didalam lingkup UU pemerintah tanpa melakukan hal-hal illegal. Penyebab dari perencanaan pajak yang rendah ini juga tentunya dipengaruhi oleh EBIT yang menurun dari tahun 2017 dan semakin signifikan di tahun 2019 menjadi sebesar -73\%. Ditambah lagi dengan perkalian depresiasi terhadap tariff pajak $\mathrm{PPh}$ Badan sebesar 25\%, perusahaan mampu mengelak dari pembayaran pajak yang besar.

Namun kedua hal tersebut saling bertolak belakang, dan memiliki manfaat yang berbeda dengan sisi pandang yang berbeda. Untuk manajemen perusahaan, tentunya hal yang diinginkan merupakan arus kas operasi yang sehat dengan pertumbuhan yang positif untuk menjaga keberlangsungan nilai perusahaan dan kepercayaan public maupun investor/kreditur (Ruzzier M., 2015). Tetapi untuk manajemen pajak, hal yang dituju adalah rendahnya beban pajak penghasilan yang dibayarkan untuk mengurangi beban dan menambah laba selama pemanfaatan loophole dalam UU pajak dapat digunakan.

Perhitungan arus kas operasi menggunakan pendekatan Tax Shield ini juga dapat sangat membantu manajemen perusahaan dalam proses pengambilan keputusan, terutama bagi sectorsektor yang memiliki asset-aset besar dan berkontinyu seperti mesin, bangunan, tanah dan yang sebgainya. Dengan mengetahui besaran arus kas operasi yang dimiliki perusahaan, manajemen dapat memutuskan dalam dua pilihan pada suatu keadaan, seperti membeli atau menyewa mesin, membeli atau menjual tanah, memperbaiki atau membeli gedung baru dan hal-hal pilihan lain yang tentunya berhubungan dengan arus kas perusahaan.

\section{KESIMPULAN}

Berdasarkan hasil dan diskusi sebelumnya, maka dapat ditarik kesimpulan-kesimpulan sebagai berikut : 
1. Pada tahun 2018, EBIT memiliki pertumbuhan sebesar -13\% dari tahun 2017 dan menurun secara signifikan menjadi $-73 \%$ di tahun 2019.

2. Pertumbuhan depresiasi di tahun 2018 sebesar $29 \%$ dari tahun sebelumnya dan menjadi $21 \%$ di tahun 2019.

3. $\mathrm{AKO} / \mathrm{OCF}$ memiliki pertumbuhan sebesar $-7 \%$ di tahun 2018 dan menurun menjadi $-55 \%$ di tahun 2019.

4. Rata-rata AKO dari Laporan Keuangan tahun 2017 sebesar - Rp. 5.971.876.057.398, sedangkan AKO dengan pendekatan Tax Shield sebesar Rp. 5.731.774.969.557. Untuk tahun 2018, rata-rata AKO dari Laporan Keuangan sebesar Rp. 2.069.681.573.043 dan dengan pendekatan Tax Shield sebesar Rp. 5.331.009.095.480. Semestara tahun 2019, AKO dari laporan keuangan sebesar Rp. 8.824.885.632.832, namun dengan pendekatan tax shield berjumlah Rp. 2.418.268.665.580.

5. Dari segi manajemen perusahaan, $\mathrm{AKO} / \mathrm{OCF}$ yang menurun menjadi masalah bagi nilai perusahaan dan harus ditingkatkan untuk menjaga kepercayaan public maupun investor/kreditur.

6. Dari segi manajemen perpajakan, AKO/OCF yang menurun menandakan Tax Shield atau perencanaan pajak yang baik karena dapat menghindari pajak untuk mengecilkan pengeluaran beban pajak penghasilan tanpa melanggar UU perpajakan.

7. Pada dasarnya perhitungan Arus Kas Operasional menggunakan pendekatan apapun seharusnya menghasilkan jumlah yang sama, baik menggunakan metode bottom-up, topdown maupun tax shield approach. Namun pendekatan tax shield dalam menghitung arus kas operasional dapat membantu analisis dari sisi yang berbeda untuk mengetahui perbedaan dari jumlah Arus Kas Operasi yang dilaporkan di Laporan Keuangan dengan jumlah Arus Kas Operasi yang dihitung menggunakan tax shield approach.

Adapun penelitian ini dilakukan dengan masih banyaknya batasan dan kekurangan baik dari segi objek, periode maupun metode yang digunakan. Bagi peneliti selanjutnya, disarankan untuk menggunakan objek yang lebih mendetail, seperti perusahaan yang memiliki asset dengan peralatan berat seperti mesin dan meneliti dengan periode yang lebih panjang yaitu 5 tahun, untuk dapat mengetahui pertumbuhan maupun perubahan dari arus kas operasional yang dilaporkan di Laporan Keuangan dan arus kas operasional yang dihitung menggunakan pendekatan tax shield. Hal ini tentunya dapat saja menghasilkan hasil atau simpulan penelitian yang berbeda, dimana hasil perhitungan Arus Kas Operasional dengan menggunakan pendekatan tax shield dapat menghasilkan jumlah yang sama dengan jumlah yang dilaporkan pada Laporan Keuangan.

\section{REFERENSI}

[1] Miqdad Zuhdy Azra. (2018), Pengantar Akuntansi 2 Berbasis IFRS. Terjemahan Jerry J.Weygant, Paul D. Kimmel, Donald E. Kieso. Jakarta: Salemba Empat.

[2] Ikatan Akuntansi Indonesia. PSAK No. 2 Tentang Laporan Arus Kas - edisi revisi 2015. Penerbit Dewan Standar Akuntansi Keuangan: PT. Raja Grafindo

[3] Fernandez, Pablo. (2010), The Value of Tax Shields is NOT Equal to the Present Value of Tax Shields. SSRN Working Paper no. 290727.

[4] Graham, J. R., and Tucker, A. (2016). Tax Shelters and Corporate Debt Policy. Journal of Finance 81(3): 563-594

[5] Miles, J.A., J.R. Ezzell, (1985). Reformulating Depreciation Tax Shield Valuation: A Note. Journal of Finance Vol XL. 5. Pp. 1485-1492.

[6] Simkova N. The Hierarchical Clustering of Tax Burden in the EU27. Journal of Competitiveness. 2015;7(3):95-109. DOI: http://doi.org/10.7441/joc.2015.03.07 
[7] Ruzzier M, Konecnik Ruzzier M. On the relationship between firm size, resources, age atentry and internationalization: the case of Slovenian SMEs. Journal of Business Economics and Management. 2015; 16(1):52-73. DOI: http://dx.doi.org/10.3846/16111699.2012.745812 